\title{
Establishment and characterization of a new gastric cancer cell line, XGC-1
}

\author{
Jigui Peng ${ }^{1,2,3 \dagger}$, Hao $\mathrm{Xu}^{2,3,4 \dagger}$ and Jianchun $\mathrm{Cai}^{1,2,3^{*}}$ (D)
}

\begin{abstract}
Background: To establish a primary human gastric cancer cell line.

Methods: Fresh gastric cancer tissue samples were separated into a cell suspension, and DMEM/F12 medium containing 10\% foetal bovine serum was used for primary culture and subculture. The morphology of the cells was observed under a light microscope, and the cell growth curve was plotted. A soft agar colony formation assay was used to detect the colony formation ability of the cell line. Immunohistochemical methods were used to detect cytokeratin, vimentin and Ki-67, the chromosome G banding method was used to analyse the karyotype of the cells, and the tumourigenic ability of the cells was detected by subcutaneous inoculation of BALB/C nude mice.
\end{abstract}

Results: We established a gastric cancer cell line from a 68-year-old male patient. This gastric cancer cell line was named XGC-1 and had a doubling time of approximately $48 \mathrm{~h}$. The cell line displayed strong colony formation ability and tumourigenicity in BALB/C nude mice and had complicated chromosomal abnormalities. When nutrients were insufficient, the cells shed and floated in the medium, but adherent growth was observed in nutrient-rich conditions.

Conclusions: The XGC-1 cell line will be useful for future studies of gastric cancer development, progression, metastasis and therapy.

Keywords: Stomach neoplasm, XGC-1, Cell line, Primary culture

\section{Background}

Gastric cancer is a common disease that causes digestive tract tumours and seriously threatens human life and health. Although the incidence of gastric cancer has declined in recent decades due to improvements in living conditions, the development of good eating habits, and the eradication of Helicobacter pylori (Hp), the incidence of gastric cancer is still high worldwide. Gastric cancer is the fourth leading cause of tumours and the third leading cause of cancer-related mortality, and its incidence in men is twice that in women $[1,2]$. China has a high incidence of gastric cancer. According to the 2015 China

\footnotetext{
*Correspondence: jianchunfh2@yeah.net

† Jigui Peng and Hao Xu contributed equally to this work

${ }^{1}$ Department of Gastrointestinal Surgery, Zhongshan Hospital of Xiamen University, Xiamen 361004, Fujian, China

Full list of author information is available at the end of the article
}

Cancer Data Report, the estimated number of new cases of gastric cancer in China was 679,000, and the number of deaths was 498,000 . The morbidity and mortality rates of gastric cancer are the second highest among malignant tumours. New cases of gastric cancer and deaths from gastric cancer in China account for $42.6 \%$ and $45.0 \%$ of the worldwide total, respectively [3].

At present, approximately $90 \%$ of gastric cancers found in China are at an advanced stage, and the prognosis of gastric cancer is closely related to the timing of diagnosis and treatment. Even if advanced gastric cancer is treated with surgery, the 5-year survival rate is still less than $30 \%$ [4]. Therefore, reducing the incidence and mortality of gastric cancer is a major public health problem that needs to be solved and will contribute to an improved quality of life for people worldwide.

The first human cancer cell line was established in a Baltimore laboratory by Gey et al. [5] over 65 years ago. 
Since then, many gastric cancer cell lines have been established from human tumours; these cell lines have served as important experimental tools in oncology research [6-12]. These cell lines have many advantages: they are very easy to handle, they are an infinite source of self-replicating cells, they have a relatively high degree of homogeneity, and they are easy to replace with frozen stocks if they become contaminated. However, these cell lines also have some shortcomings; cell lines easily undergo genotypic and phenotypic drift in culture, and this drift is particularly frequent in the more commonly used cell lines, especially those that have been deposited in cell banks for many years. In addition, through specific mutations, some subpopulations that show rapid growth or increased malignancy may arise over time [12-15].

A well-established tumour cell bank should reflect the diversity of tumour phenotypes and provide heterogeneous cell lines. At the same time, due to racial and regional differences, new cell lines with different backgrounds should be established, which is important for analysis of the role of regional differences in tumourigenesis and development [16]. Other important considerations for cell lines are cross-contamination, tumour heterogeneity and misidentification [17-19]. Researchers can draw erroneous conclusions or encounter serious bias when using these cell lines [14]. Despite our growing understanding of this disease, the exact molecular and genetic processes that cause gastric cancer remain largely unknown; therefore, further elucidation of the molecular pathogenesis of this disease is necessary, and the establishment of different gastric cancer cell lines will be essential.

For the above reasons, primary cell culture and the establishment of new cell lines are still important at this stage. We report a new human gastric cancer cell line, XGC-1, from a Chinese patient. This newly established cell line will be a useful model for the study of gastric cancer pathogenesis.

\section{Methods}

\section{Specimen collection}

The specimens used in this study were obtained with written informed consent from a 68-year-old Chinese male patient who underwent surgical resection at the First Affiliated Hospital of Xiamen University (Xiamen, P.R. China) for gastric cancer in the fundal junction of the stomach. The size of the original tumour was $3.5 \times 4.3 \mathrm{~cm}$. No distant metastasis was detected at the time of surgical resection. The tumour was histopathologically classified as a poorly differentiated gastric adenocarcinoma.

\section{$B A L B / C$ nude mice}

BALB/C nude mice were purchased from Shanghai Slac Laboratory Animals Co., Ltd., and kept in the animal experiment centre of Xiamen University.

The animal experiments were carried out according to the requirements of the Xiamen University Experimental Animal Care Commission. If an animal became severely ill during the experiment, the animal was humanely killed by $\mathrm{CO}_{2}$ inhalation combined with cervical dislocation to confirm death and prevent animal suffering. Pathogenfree BALB/C nude mice aged 4 weeks old were housed in filter-top cages, and sterile water and food were given ad libitum. The mice weighed $15-18 \mathrm{~g}$ at the beginning of the experiment. All manipulations were conducted aseptically inside a laminar flow hood.

The following methods were similar or identical to those employed in previous studies [12, 20].

\section{Establishment of the XGC-1 cell line}

Tumour specimens were rinsed twice with sterile phosphate-buffered saline (PBS) containing antibiotics. Then, the samples were enzymatically disaggregated after incubation with collagenase type II and neutral protease solution at $37^{\circ} \mathrm{C}$ in a humidified atmosphere containing $5 \% \mathrm{CO}_{2}$. After the samples were incubated for approximately $0.5 \mathrm{~h}, 5 \mathrm{ml}$ of foetal calf serum (FBS) (Gibco, Grand Island, NY, USA) was added to terminate the digestion. Then, the digested tumour fragments and fluid were filtered through a 200 mesh sieve, and the filtrate was centrifuged at $1000 \mathrm{rpm}$ for $5 \mathrm{~min}$. The supernatant was removed, and the remaining cells were resuspended in Dulbecco's modified Eagle's medium (DMEM) and Ham's F-12 medium (1:1) (Gibco) supplemented with penicillin $(100 \mathrm{U} / \mathrm{ml})$, streptomycin $(100 \mu \mathrm{g} / \mathrm{ml})$, heatinactivated $2 \%$ FBS, hEGF $(0.1 \mathrm{ng} / \mathrm{ml})$, bFGF $(0.1 \mathrm{ng} /$ $\mathrm{ml})$, hydrocortisone $(25 \mu \mathrm{g} / \mathrm{ml})$, fluconazole $(40 \mu \mathrm{g} /$ $\mathrm{ml})$ (Gibco), and M-plasmocin (25 $\mu \mathrm{g} / \mathrm{ml})$ (Invitrogen); seeded in 12-well culture plates; and cultivated at $37{ }^{\circ} \mathrm{C}$ in a humidified atmosphere of $5 \% \mathrm{CO}_{2}$ in air. The growth medium was replaced every $2-3$ days, and the plate was regularly assessed for epithelial cell and fibroblast outgrowth. When the cells completely covered the bottom of the plate, they were passaged. Currently, the cell line has been cultured for $>90$ passages. The cells were tested for mycoplasma contamination, and the result was negative. The cell line was designated XGC-1 (Xiamen gastric cancer-1).

\section{Short tandem repeat analysis for authentication}

To authenticate the established cell line, we analyzed short tandem repeats (STRs) of the XGC-1 cells and the original tumor tissue. The data were analyzed, and the 
STR profiles were compared with those recorded in public cell banks, such as the ATCC, CCTCC, and JRCB, for reference matching.

\section{Morphology of the XGC-1 cell line}

XGC-1 cells were seeded in 6-well plates and incubated at $37{ }^{\circ} \mathrm{C}$ in a humidified atmosphere containing $5 \% \mathrm{CO}_{2}$ for 2 weeks. Every day, the cells were placed under an inverted microscope to observe their general morphology. Cell ultrastructure was observed under a transmission electron microscope.

\section{Cell growth properties}

Cells were plated in 96-well plates at 1000 cells/well and cultured in DMEM/F12 containing 10\% FBS for various durations. Cell numbers were measured by MTT assays, which were performed according to the manufacturer's protocol. The doubling times were determined from the growth curve.

\section{Colony-forming efficiency}

Colony formation of different cell clones in soft agar was used to assess their growth capabilities. A single-cell suspension $\left(1 \times 10^{4}\right.$ cells $\left./ \mathrm{ml}\right)$ was prepared. Agar $(0.6 \%)$ was mixed with DMEM/F12 and added to 6-well plates as the lower layer. Then, $0.3 \%$ agar was mixed with the cell suspension, and the mixture was added to the same 6-well plate as the upper layer. Every well contained 1000 cells. The plates were incubated at $37{ }^{\circ} \mathrm{C}$ in a humidified incubator containing $5 \% \mathrm{CO}_{2}$. Fourteen days later, cell colonies were counted with a microscope, and the colony formation rates were calculated using the following formula: colony formation rate $(\%)=$ (number of colonies/ number of cells inoculated) $\times 100 \%$.

\section{Chromosome analysis}

Cells were karyotyped using a standard air-drying method after treatment with a final concentration of $0.05 \mathrm{mg} / \mathrm{ml}$ colcemid for $2 \mathrm{~h}$ when the cells were in the exponential growth phase. The cells were analysed using trypsin $\mathrm{G}$ banding. A total of 200 metaphase spreads were examined to determine the modal number. Karyotyping was performed according to the International System for Human Cytogenetic Nomenclature (2005). Chromosome analysis was carried out on the cell line at passage 40 .

\section{Tumourigenicity in BALB/C nude mice}

The study protocol for mice was approved by the Xiamen University Experimental Animal Care Commission. Briefly, cells at passage 45 were prepared to determine their tumourigenicity in BALB/C nude mice. Cultured cells $\left(1 \times 10^{6}\right.$ cells $\left./ \mathrm{ml}\right)$ were harvested, washed, resuspended in $0.1 \mathrm{ml}$ of complete DMEM/F12, and injected subcutaneously into the right flanks of three 4-week-old female BALB/C nude mice. The animals were examined every week for the development of tumours. Tumourbearing mice were sacrificed. Tumour tissue was excised, fixed in $10 \%$ formalin, and processed for routine histopathological examination.

\section{Immunohistochemistry}

Cell monolayers at passage 35 were subcultured and grown on sterile microscope slides. After confluent growth was observed, the slides were washed with PBS, fixed in $4 \%$ paraformaldehyde for $15 \mathrm{~min}$, air-dried and treated with $0.5 \%$ Triton X-100 for 20 min. PBS was used as the negative control, and the slides were then overlaid with the following antibodies: a mouse monoclonal antibody directed against human cytokeratin, a rabbit monoclonal antibody directed against Ki-67, and a mouse monoclonal antibody directed against human vimentin, mouse monoclonal antibody directed against human carcinoembryonic antigen, mouse monoclonal antibody directed against human cancer antigen 19-9. The slides were incubated with the antibodies for $60 \mathrm{~min}$ and thoroughly washed with PBS. Biotinylated rabbit anti-mouse IgG was subsequently applied for $15-20 \mathrm{~min}$, and the samples were washed. Then, a solution of DAB was added to the slides, and the slides were incubated for 1-5 min at room temperature. Finally, the slides were rinsed with distilled water, counterstained with haematoxylin and eosin (H\&E) and examined by light microscopy.

\section{Statistical analysis}

The statistical significance of differences between experimental groups and controls was determined by Student's t-test. Values of $\mathrm{P} \leq 0.05$ were considered statistically significant.

\section{Results}

We successfully established a new gastric cancer cell line, XGC-1, in vitro using a fresh sterile specimen derived from the primary tumour of a gastric cancer patient. It was confirmed that XGC-1 cells did not correspond to any cells deposited in public cell banks (Table 1). From the primary culture, we succeeded in freezing, thawing and subculturing cells for $>90$ generations in DMEM/F12 supplemented with $10 \%$ FBS.

\section{In vitro characteristics of XGC-1 cells}

Under light microscopy, most of the cells appeared spindle-shaped and oval-shaped, a few cells were polygonal, the cell poles appeared sharp, the nuclei were obvious, a few cells were multinucleated, and the nucleolus was clearly visible (Fig. 1a). The cells aggregated and grew during culture. When the nutrient level was insufficient, 
Table 1 Results of STR analysis

\begin{tabular}{lll}
\hline $\begin{array}{l}\text { Microsatellite } \\
\text { (chromosome) }\end{array}$ & XGC-1 (P90) & Tumor tissue \\
\hline Amelogenin & X,Y & X,Y \\
TH01 & 9 & 9 \\
D21S11 & 29 & 29 \\
D5S818 & 10,13 & 10,13 \\
D13S317 & 9,11 & 9,11 \\
D7S820 & 11 & 11 \\
D16S539 & 11,12 & 11,12 \\
CSF1PO & 11,13 & 11,13 \\
VWA & 16,17 & 16,17 \\
TPOX & 8 & 8 \\
\hline
\end{tabular}

$P$ indicates the passage number of a cell line

the cells floated in the culture medium, and they continued to adhere to the wall in nutrient-rich conditions (Fig. 1b). H\&E staining showed that the nuclei were deeply stained and the proportion of nucleoplasm was high, which is consistent with cancer cell characteristics (Fig. 1c). Transmission electron microscopy revealed that most cell nuclei increased in volume, were round or elliptical, and had a large proportion of nucleoplasm. Chromatin in the nucleus was often significant, part of the nuclear membrane was recessed, and the nucleolus was significantly enlarged and solid; the number of free ribosomes increased and there were fewer organelles, mitochondrial swelling was obvious, the crest morphology was irregular and the crest number was small, the connection between the cells was scarce, and there were no microvilli structures (Fig. 1d). The cells were passaged $>90$ generations, and there was no obvious change in morphology during cell passage. The growth of the XGC-1 cell line was assayed by the MTT method. The XGC-1 cell line showed vigorous growth and a doubling time of approximately $48 \mathrm{~h}$ (Fig. 1e).

\section{Colony-forming efficiency}

The cells began to divide on the third day of culture in low-melting agarose, and colonies were formed in the independent single-cell culture at 2 weeks. The cells were stacked in a circular shape, and white colonies were observed with the naked eye at 3 weeks. The colony formation rate was approximately $72.0 \%$ (Fig. $2 \mathrm{a}$, b).

\section{Karyotype of the XGC-1 cell line}

The karyotype was triploid, many deletions were observed, ectopic and derived chromosomes $(\rightarrow)$ were visible, the $\mathrm{X}$ chromosome had an abnormal arm, the $\mathrm{Y}$ chromosome was lost, no normal chromosome 3 was present, the Philadelphia chromosome $\left(\mathrm{Ph}^{\prime}\right)$ was observed, and 4 chromosomes with unknown sources were detected. The representative karyotype was $69, \mathrm{X}$, $-\mathrm{Y}, \operatorname{der}(\mathrm{X}) \operatorname{add}(\mathrm{X})(\mathrm{P}$ ?), $\mathrm{i}(\mathrm{X})(\mathrm{p} 10), \operatorname{der}(1) \operatorname{add}(1)(\mathrm{p}$ ?), $\operatorname{der}(1)$ $\operatorname{add}(1)(\mathrm{p} ?),-2, \operatorname{del}(3)(\mathrm{q} 10), \operatorname{der}(3) \mathrm{t}(3 ; 5)(\mathrm{p} 10 ; \mathrm{q} 10), \operatorname{der}(3)$ $\mathrm{t}(3 ; 9)(\mathrm{q} 10 ; \mathrm{p} 10),-4, \operatorname{del}(4)(\mathrm{p} 10), \operatorname{der}(4) \operatorname{del}(4)(\mathrm{p} 15) \operatorname{add}(4)$ $(\mathrm{q}$ ?), $-5, \mathrm{i}(5)(\mathrm{p} 10) \times 2, \quad \operatorname{del}(6)(\mathrm{q} 21),+\operatorname{der}(7) \operatorname{add}(7)(\mathrm{p} ?)$, $\operatorname{del}(9)(\mathrm{p} 21),-10,-11,-13, \operatorname{der}(13) \operatorname{add}(13)(\mathrm{p} ?),-14$, $\operatorname{del}(17)(q 24),-18, \operatorname{del}(22)(q 11),+\operatorname{mar} 1,+\operatorname{mar} 2,+\operatorname{mar} 3$, + mar4 (Fig. 3a, b).

\section{Histological examination}

Subcutaneous inoculation for 5 days resulted in a mung bean-sized tumour. One month later, the BALB/C nude mice were sacrificed (Fig. 4a). The subcutaneous tumours were removed for histological examination (Fig. 4b) and were compared with the original primary tumour. Both primary tumours and subcutaneous tumours (Fig. 4c, d) were characterized by typical gastric adenocarcinoma (H\&E) features, and all were poorly differentiated. The liver, kidney, lung and other important organs showed no tumour metastasis.

\section{Immunohistochemistry}

PBS was used as the negative control (Fig. 5a). The results of immunohistochemical staining revealed that cytokeratin expression was positive (Fig. 5b), and cytoplasmic keratin was stained a tan colour. The membrane and nucleus were not stained, and vimentin expression was negative (Fig. 5c). Cytoplasmic vimentin staining was not observed, which was consistent with the epithelial source characteristics. Nuclear Ki-67 was stained brown (Fig. 5d). Carcinoembryonic antigen was positive in XGC-1 cells (Fig. 5e), while cancer antigen 19-9 was negtive. The patina and capsule were not stained, and 5 fields were randomly observed under a microscope. The average staining rate of the fields of view was approximately $75 \%$.

(See figure on next page.)

Fig. 1 Morphology of XGC-1 cells. a Micrographs of XGC-1 cells at different passages under phase contrast (A1: passage 1; A2: passage 10; A3: passage 20; A4: passage 30; A5: passage 40; A6: passage 50. Magnification, $\times 200$ ). $\mathbf{b}$ When nutrients are insufficient, the cells will fall off the plate into the culture medium (magnification, $\times 200$ ). c H\&E staining showed large nuclei and prominent nucleoli (magnification, $\times 200)$. d Ultrastructural appearance of XGC-1 cells (magnification, $\times 8000$ ). e The growth curve of XGC-1 cells 

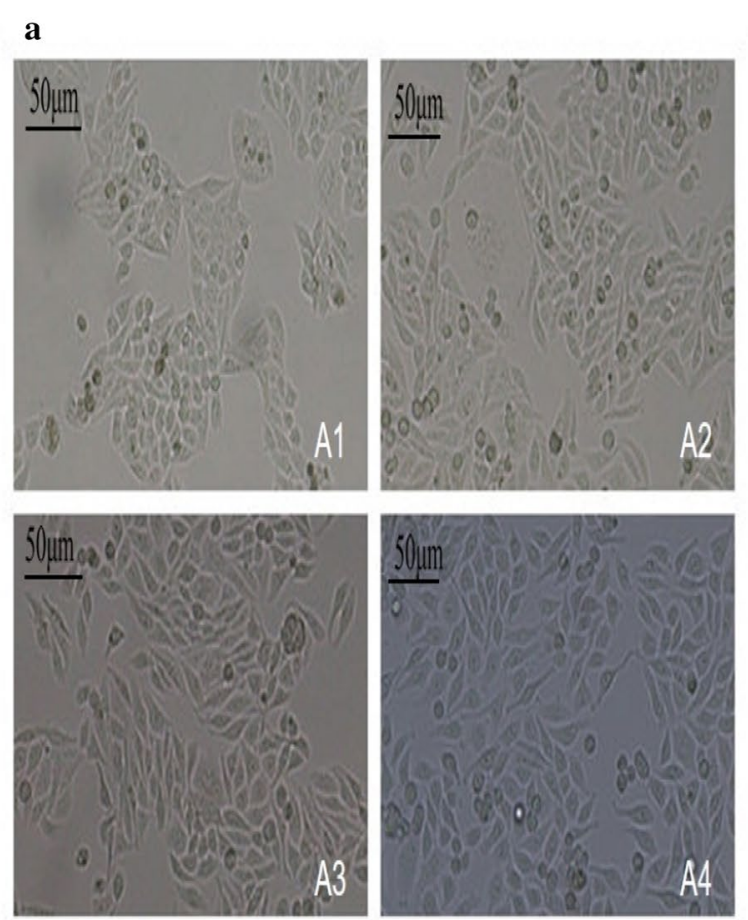

b
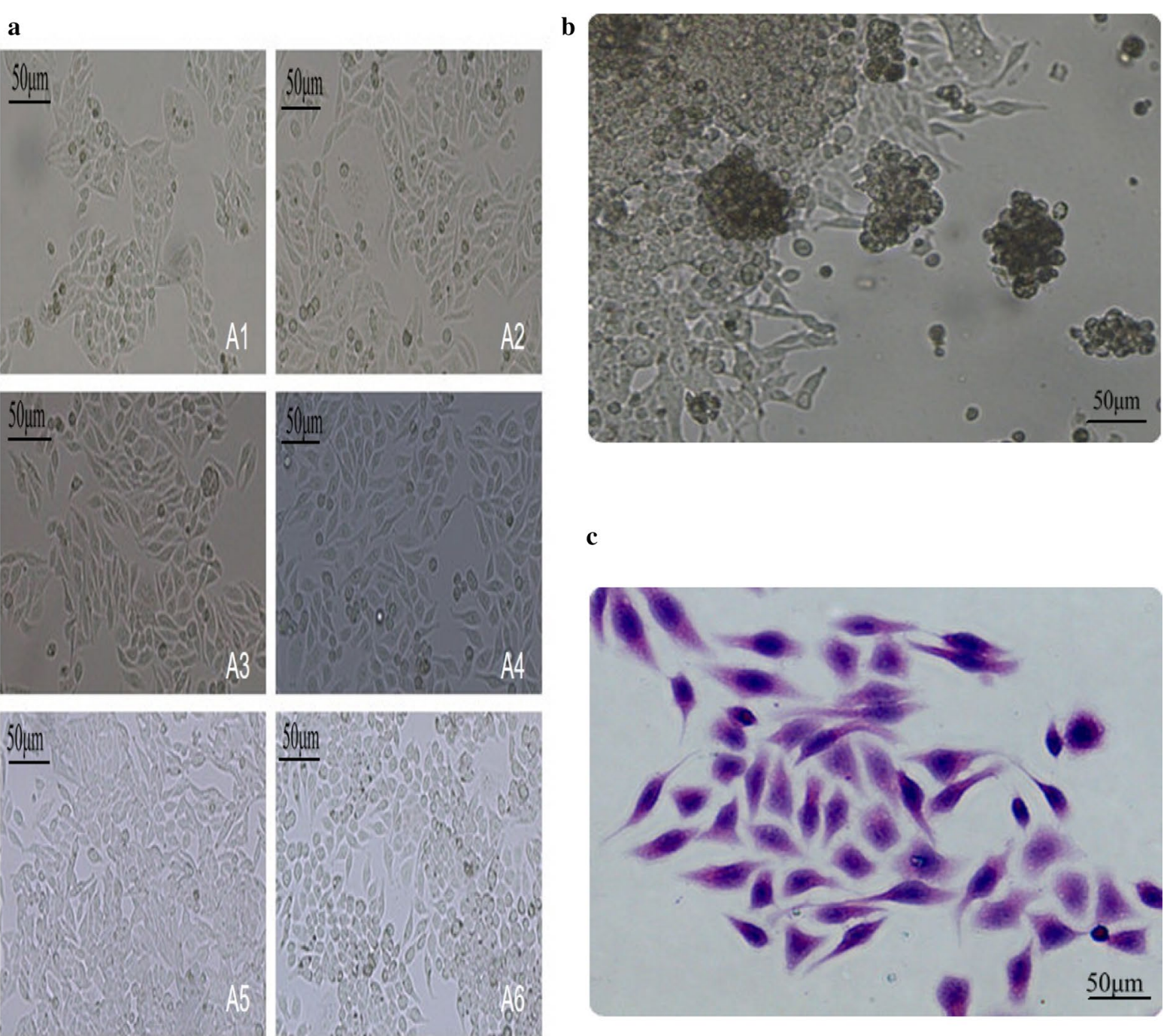

\section{d}
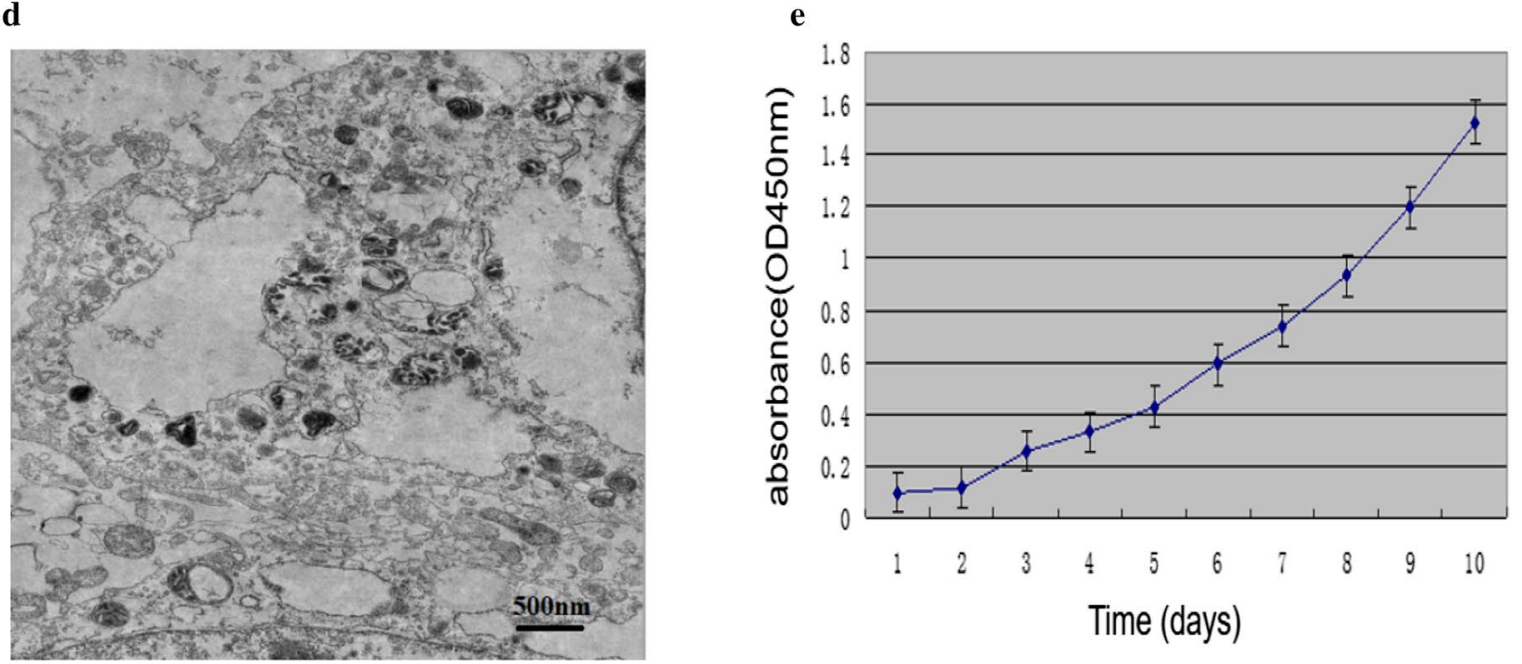

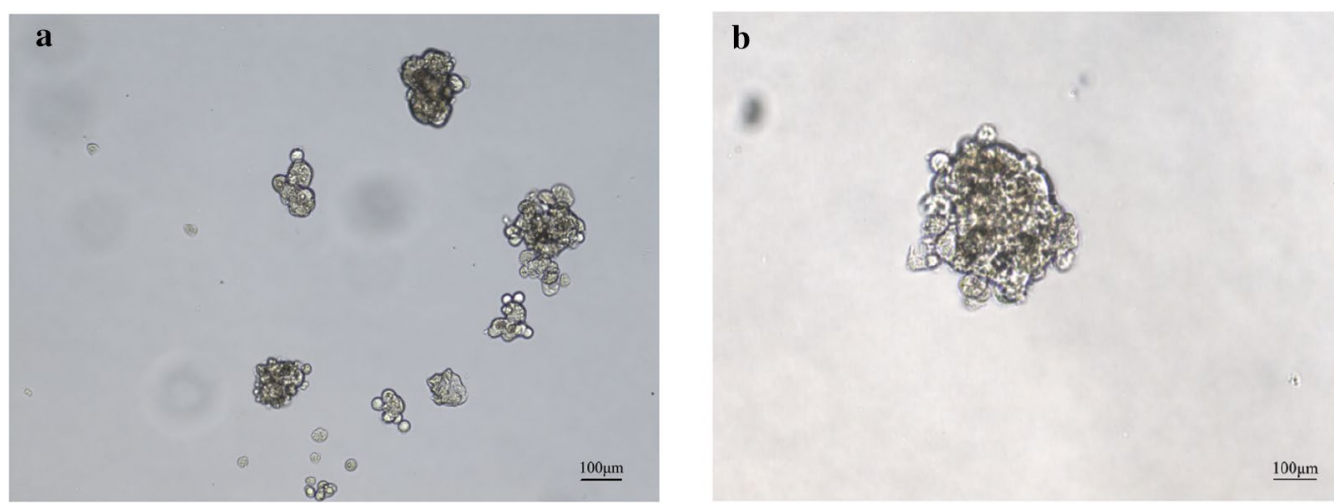

Fig. 2 The anchorage-independent growth capability of XGC-1 cells in vitro. XGC-1 cells were plated in 0.3\% agar supplemented with $10 \%$ FBS for 2 weeks to test the formation of colonies. a Colony formation for 1 week. $\mathbf{b}$ Colony formation for 2 weeks

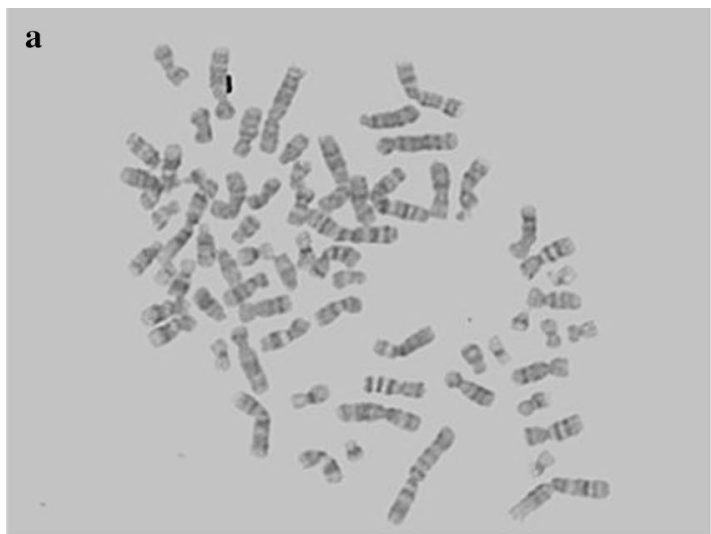

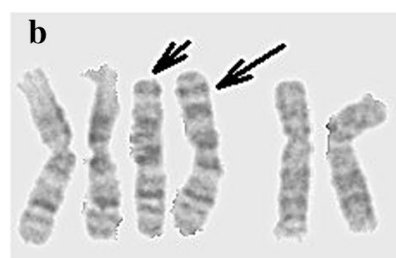

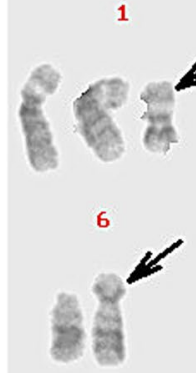

13
2

.

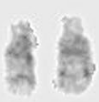

14
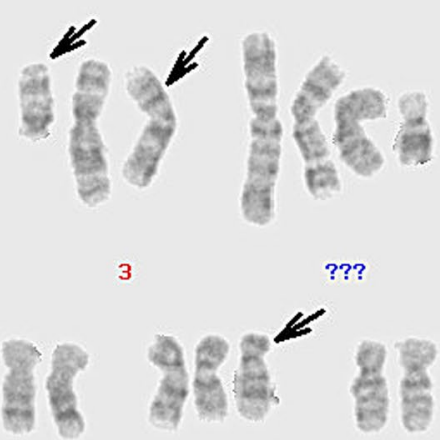

9

8

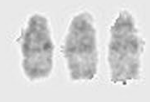

15
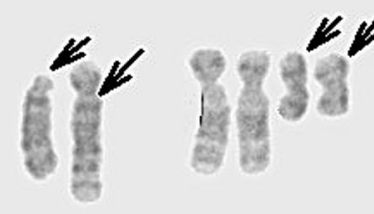

4

10

11

12
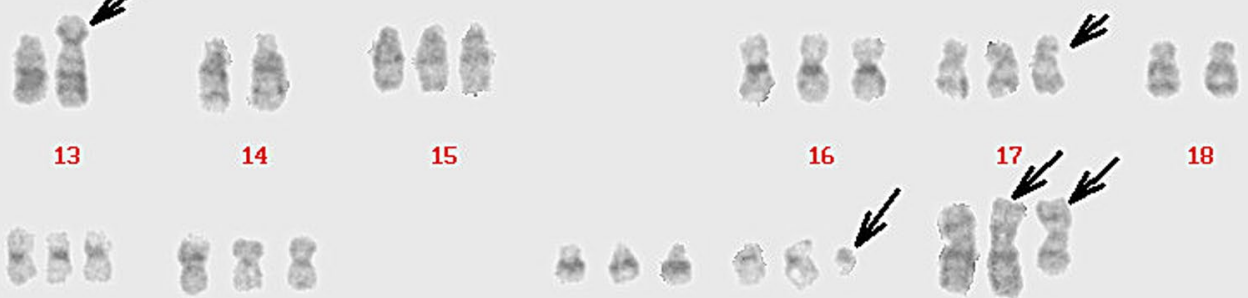

B. 8 \& 앙 8

16

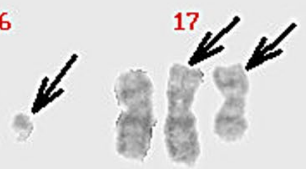

18

19

20

21

22

$\mathrm{x}$

Y

Fig. 3 Karyotype analysis of the XGC-1 cell line. The karyotype of the XGC-1 cell line shows abnormalities in both the number and structure of chromosomes 

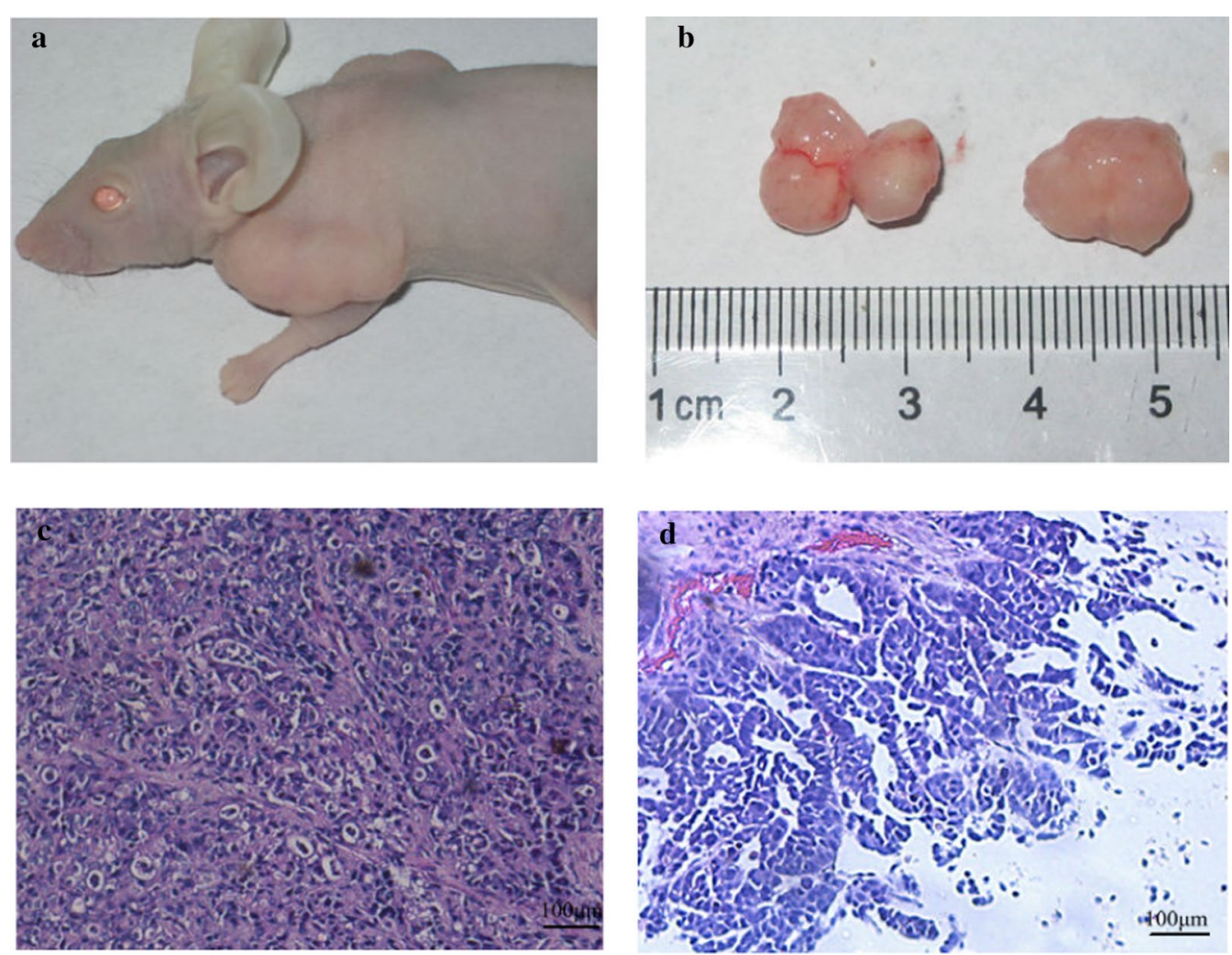

Fig. 4 Tumourigenicity of XGC-1 cells in nude mice. a BALB/C nude mice were injected subcutaneously with $1 \times 10^{6}$ cells for 4 weeks, the mice were sacrificed, and the tumours were excised for histopathological examination. $\mathbf{b}$ The solid tumour was obtained. $\mathbf{c}$ Histology of primary tumours formed by XGC-1 cells showed poorly differentiated gastric cancer, and the structure of the gland was seen (magnification, $\times 100)(H \& E)$. d Histology of xenografted tumours of XGC-1 cells showed poorly differentiated gastric cancer, and the structure of the gland was observed (magnification, $\times 100)(H \& E)$

\section{Discussion}

The establishment of various gastric cancer cell lines can provide materials for analysing the characteristics of different types of gastric cancer. By analysing the characteristics and commonalities of different gastric cancer cell lines, researchers can reveal the mechanisms underlying the occurrence and development of gastric cancer and lay a theoretical foundation for the clinical treatment of gastric cancer. Recent studies have also found that differences in regional factors can affect tumour characteristics in cancer patients, leading to different clinical outcomes [16]. For the above reasons, primary cell culture and the establishment of new cell lines are still important at this stage.

In this study, a gastric cancer cell line (XGC-1) derived from a primary tumour that was shown to have characteristics of poorly differentiated adenocarcinoma was established from a male Chinese patient. Immunohistochemistry of the gastric cancer cell line showed that the cells were derived from epithelial cells, cell proliferation was active, and staining for the proliferating cell nuclear antigen Ki-67 was $\geq 75 \%$. Ki-67 is a cell cycle-associated protein that is closely related to tumourigenesis and development. The degree of Ki-67 expression can reflect the proliferation of tumours and can be used to predict the prognosis of patients; patients with high expression have a poor prognosis [21-23].

In this cell line, single cells cultured in agarose can grow independently and proliferate, and the doubling time does not change significantly. The colony formation rate is high, clones can be formed in 2 weeks, and cell colony formation can be observed with the naked eye at 3 weeks. At the same time, the tumour formation experiment in nude mice confirmed that 100,000 cancer cells can form tumours under the skin, and the growth rate of the tumour is rapid. The tumour size of a grain of rice can be observed within 5 days of inoculation, and the volume at 1 month reached $1 \times 1.5 \mathrm{~cm}^{3}$. These characteristics indicate that the cell line has high cell viability, inactivation of the growth regulatory mechanism, strong cell 

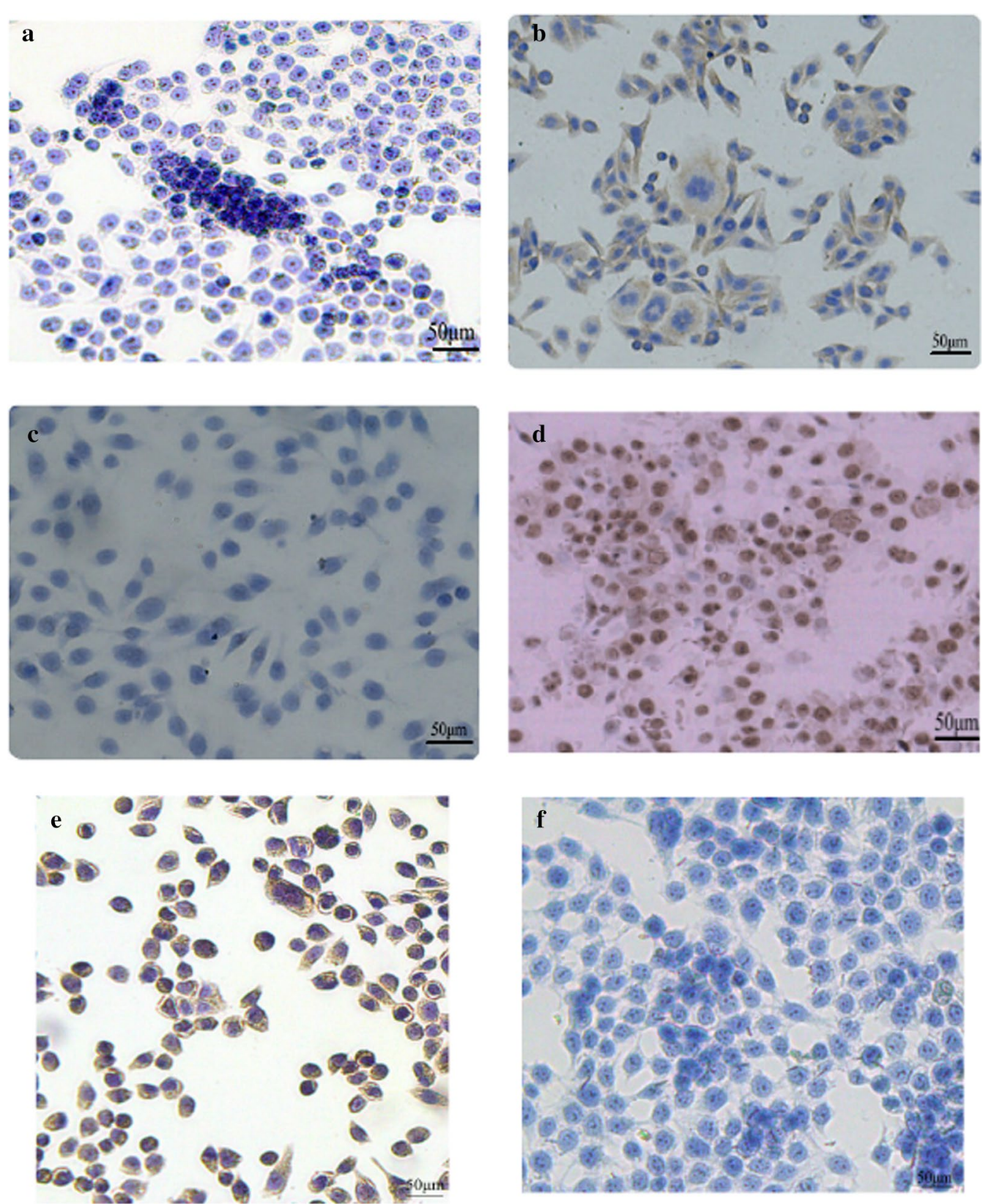

Fig. 5 Immunohistochemistry of XGC-1 cells (magnification, $\times 200$ ). a PBS was used as a negative control. b XGC-1 cells exhibited positive results for cytokeratin. $\mathbf{c}$ The cells were negative for vimentin. $\mathbf{d}$ Ki-67 was expressed at very high levels in the nucleus ( $\geq 75 \%)$. e Carcinoembryonic antigen was positive in XGC-1 cells. $\mathbf{f}$ Cancer antigen 19-9 was negtive

independence, and strong metabolism. Thus, this line can be used for analysis of cancer stem cells and the mechanisms regulating cell proliferation and can also be used for related research on treatments and tumour apoptosis. Infinite proliferation is one of the characteristics of tumour cells. This cell line has been passaged for $>90$ generations. During the culture process, the cells can be stably passaged, and the morphology is unchanged.
For a human-derived malignant tumor, it is generally considered that it has strong invasion and metastasis capabilities, but for nude mice, this malignant tumor is actually just a benign tumor, and the differences between species also affect tumor cells. For example, if a lowgrade human-derived tumor cell is injected into the tail vein, it may not grow in nude mice, and a highly malignant tumor cell is rarely seen in nude mice. Especially for 
studies focusing on tumor metastasis, the nude mouse experimental model will cause great difficulties in the interpretation of subsequent results. Because the metastatic behavior is closely related to the environment, nude mice have no $\mathrm{T}$ cell immunity and a xenogenic growth environment. Of course, the site of tumor cell inoculation may also be related to the occurrence of metastasis. The influence of these factors on tumor metastasis cannot be ignored, and the conclusion of the experiment should be cautious.

The cells can be superimposed on each other and grow in a mass. When the nutrient level is insufficient, the cells will fall off the surface and float, and when the nutrient level is sufficient, they will reattach to the wall. Although the established cell line was derived from in situ gastric cancer tissue, its growth pattern indicates that the cell line has metastatic tumour characteristics, which may be related to high malignancy and poor prognosis. Whether the cell adhesion-shedding-adherent growth progression is the same as the mechanism of clinical tumour metastasis and whether the overgrowth of tumour cells leads to a lack of cell nutrition and tumour metastasis remain unknown. The relevant effects on prognosis should be examined in the future.

Chromosomal instability is mainly manifested by changes in chromosome structure and quantity. The chromosomes of early tumour cells are mostly diploid, and chromosome instability increases with tumour progression and is often accompanied by changes in chromosome number and the generation of hybrid DNA $[24,25]$. In gastric cancer, chromosomal instability is one of the main causes of genetic instability. Chromosomal deletion, cleavage and rearrangement lead to the activation of oncogenes or the inactivation of tumour suppressor genes, which promotes tumourigenesis and development [26, 27]. Therefore, the establishment of a gastric cancer cell line with chromosomal instability is conducive to study the relationship between the occurrence of gastric cancer and genetic instability. In this gastric cell line, many chromosomal deletions and ectopic and derived chromosomes were found. Among them, the Y chromosome was lost, chromosome 3 was obviously changed, and no normal chromosome 3 was observed. The karyotype also showed the Philadelphia chromosome and chromosomes with an unknown source. Abnormal chromosome 3 is present in many gastric cancer cells and is closely related to the occurrence of gastric cancer. Abnormal chromosome 3 causes the activation of oncogenes or the inactivation of tumour suppressor genes, leading to the occurrence of gastric cancer [28]. Previous studies found that the common fragile site on chromosome 3 is unstable during DNA replication and is prone to heterozygous ectopic loss [29]. Ectopic loss of this site results in gene inactivation of a tumour suppressor gene, fragile histidine trimer (FHIT). Low expression of the FHIT gene plays an important role in the prognosis of gastrointestinal tumours [30]. The gastric cancer cell line established in this study may be used to study the relationship between gastric cancer and chromosome 3 .

\section{Conclusions}

In conclusion, we report the establishment and characterization of a new human gastric cancer cell line that was derived from a primary tumour and named XGC-1. The gastric cancer cell line has strong cell viability, a high tumour formation rate, high malignancy and metastatic ability. This line can be used as a resource for analyses of the mechanisms underlying the pathogenesis, invasion and metastasis of gastric cancer and as a foundation for diagnosis and treatment.

\section{Abbreviations}

Hp: Helicobacter pylori; PBS: Phosphate-buffered saline; FBS: Foetal bovine serum; DMEM: Dulbecco's modified Eagle's medium; H\&E: Haematoxylin and eosin; Ph': Philadelphia chromosome; FHIT: Fragile histidine triad.

\section{Acknowledgements}

We thank Qicong Luo and other colleagues in the laboratory for their helpful discussions and valuable assistance. We also would like to thank the experts who carefully read our manuscript and the editors who gave our article a chance to be published.

\section{Authors' contributions}

CJ and PJ participated in the whole project, designed the experiments and analysed the data. CJ, PJ and XH performed the experiments, analysed the data, wrote the manuscript and prepared the figures. CJ, PJ and XH contributed to the experiments and provided technical and theoretical support. All authors read and approved the final manuscript.

\section{Funding}

This work is supported, in part, by the National Natural Science Foundation of China (Nos. 81172283, 81372616 and 81871979), the Natural Science Foundation of Fujian Province (Nos. 2012D037 and 2017J01370), the Fujian Provincial Medical Innovation Project (No. 2017-CXB-15), and the Natural Science Foundation of Xiamen (No. 3502Z20174076). The funders did not have any role in the design of the study, the collection and analysis of the data, or the preparation or publication of the manuscript.

\section{Availability of data and materials}

The datasets used and/or analysed during the current study are available from the corresponding author upon reasonable request.

\section{Ethics approval and consent to participate}

The experiment was approved by the Ethics Committee of the First Affiliated Hospital of Xiamen University. The subjects were asked to fill out the informed consent form before the experiment. The xenograft study described in the present paper was approved by the Xiamen University Experimental Animal Care Commission.

\section{Consent for publication}

Consent to publish the individual data was obtained in writing from the patient in this study.

Competing interests

The authors declare that they have no competing interests. 


\section{Author details}

${ }^{1}$ Department of Gastrointestinal Surgery, Zhongshan Hospital of Xiamen University, Xiamen 361004, Fujian, China. ${ }^{2}$ Institute of Gastrointestinal Oncology, Medical College of Xiamen University, Xiamen 361004, Fujian, China. ${ }^{3}$ Xiamen Municipal Key Laboratory of Gastrointestinal Oncology, Xiamen 361004, Fujian, China. ${ }^{4}$ The Second Department of General Surgery, the First Hospital of Lanzhou University, No. 1, Donggang West Road, Lanzhou 730000, Gansu, China

Received: 23 May 2020 Accepted: 1 September 2020

Published online: 05 September 2020

\section{References}

1. Torre LA, Bray F, Siegel RL, Ferlay J, Lortet-Tieulent J, Jemal A. Global cancer statistics, 2012. CA Cancer J Clin. 2015;65:87-108.

2. Ferlay J, Soerjomataram I, Dikshit R, Eser S, Mathers C, Rebelo M, et al. Cancer incidence and mortality worldwide: sources, methods and major patterns in GLOBOCAN 2012. Int J Cancer. 2015;136:E359-86.

3. Chen W, Zheng R, Baade PD, Zhang S, Zeng H, Bray F, et al. Cancer statistics in China, 2015. CA Cancer J Clin. 2016:66:115-32.

4. Katai H, Ishikawa T, Akazawa K, Isobe Y, Miyashiro I, Oda I, et al. Five-year survival analysis of surgically resected gastric cancer cases in Japan: a retrospective analysis of more than 100,000 patients from the nationwide registry of the Japanese gastric cancer association (2001-2007). Gastric Cancer. 2018;21:144-54.

5. Gey GO, Coffman WD, Kubicek MT. Tissue culture studies of the proliferative capacity of cervical carcinoma and normal epithelium. Cancer Res. 1952;12:264-5.

6. Barranco SC, Townsend CM, Casartelli C, Macik BG, Burger NL, Boerwinkle WR, et al. Establishment and characterization of an in vitro model system for human adenocarcinoma of the stomach. Cancer Res. 1983;43:1703-9.

7. Motoyama T, Hojo H, Watanabe H. Comparison of seven cell lines derived from human gastric carcinomas. Acta Pathol Jpn. 1986;36:65-83.

8. Park JG, Frucht H, LaRocca RV, Bliss DP Jr, Kurita Y, Chen TR, et al. Characteristics of cell lines established from human gastric carcinoma. Cancer Res. 1990;50:2773-80.

9. Park JG, Yang HK, Kim WH, Chung JK, Kang MS, Lee JH, et al. Establishment and characterization of human gastric carcinoma cell lines. Int J Cancer. 1997;70:443-9.

10. Ku JL, Kim KH, Choi JS, Kim SH, Shin YK, Chang HJ, et al. Establishment and characterization of six human gastric carcinoma cell lines, including one naturally infected with epstein-barr virus. Cell Oncol (Dordr). 2012;35:127-36.

11. Akiyama S, Amo H, Watanabe T, Matsuyama M, Sakamoto J, Imaizumi M et al. Characteristics of three human gastric cancer cell lines, NU-GC-2, NU-GC-3 and NU-GC-4. Jpn J Surg. 1988;18:438-46.

12. Xu H, Peng JG, Zhuang YF, Chen JJ, Luo QC, Huang WF, et al. Establishment and characterization of an expanding-type gastric cancer cell line by Ming's classification. Oncol Rep. 2016;36:3030-6.

13. Holliday DL, Speirs V. Choosing the right cell line for breast cancer research. Breast Cancer Res. 2011;13:215.

14. Burdall SE, Hanby AM, Lansdown MR, Speirs V. Breast cancer cell lines: friend or foe? Breast Cancer Res. 2003;5:89-95.

15. Osborne CK, Hobbs K, Trent JM. Biological differences among MCF-7 human breast cancer cell lines from different laboratories. Breast Cancer Res Treat. 1987;9:111-21.

16. Lin SJ, Gagnon-Bartsch JA, Tan IB, Earle S, Ruff L, Pettinger K, et al. Signatures of tumour immunity distinguish Asian and non-Asian gastric adenocarcinomas. Gut. 2015;64:1721-31.
17. Capes-Davis A, Theodosopoulos G, Atkin I, Drexler HG, Kohara A, MacLeod RA, et al. Check your cultures! A list of cross-contaminated or misidentified cell lines. Int J Cancer. 2010;127:1-8.

18. Christgen M, Lehmann U. MDA-MB-435: the questionable use of a melanoma cell line as a model for human breast cancer is ongoing. Cancer Biol Ther. 2007;6:1355-7.

19. Cheung PF, Yip CW, Ng LW, Lo KW, Wong N, Choy KW, et al. Establishment and characterization of a novel primary hepatocellular carcinoma cell line with metastatic ability in vivo. Cancer Cell Int. 2014;14:103.

20. Zhu Y, Yang R, Gao J, Zhang Y, Zhang G, Gu L. Establishment and characterization of a novel childhood acute lymphoblastic leukemia cell line, HXEX-ALL1, with chromosome 9p and 17p deletions. Cancer Cell Int. 2019;19:113.

21. Albagli O, Pelczar H. Ki67: a surfactant of mitotic chromosomes. Med Sci (Paris). 2019;35:732-5.

22. Van Dijkum EJMN. ASO author reflections: pancreatic neuroendocrine tumor recurrence and survival predicted by Ki67. Ann Surg Oncol. 2019:26:531-2.

23. Kloppel G, La Rosa S. Correction to: Ki67 labeling index: assessment and prognostic role in gastroenteropancreatic neuroendocrine neoplasms. Virchows Arch. 2018;472:515.

24. McClelland SE. Role of chromosomal instability in cancer progression. Endocr Relat Cancer. 2017;24:T23-31.

25. Johnson SC, McClelland SE. Watching cancer cells evolve through chromosomal instability. Nature. 2019;570:166-7.

26. Chromosomal instability drives metastasis independent of aneuploidy. Cancer Discov. 2018:8:OF7.

27. Li J, Dallmayer M, Kirchner T, Musa J, Grunewald TGP. PRC1: linking cytokinesis, chromosomal instability, and cancer evolution. Trends Cancer. 2018;4:59-73.

28. Chen Z, Raghoonundun C, Chen W, Zhang Y, Tang W, Fan X, et al. SETD2 indicates favourable prognosis in gastric cancer and suppresses cancer cell proliferation, migration, and invasion. Biochem Biophys Res Commun. 2018;498:579-85

29. Fields AP, Justilien V, Murray NR. The chromosome $3 q 26$ OncCassette: a multigenic driver of human cancer. Adv Biol Regul. 2016;60:47-63.

30. Zavalhia LS, Medeiros AW, Silva AO, Roehe AV. Do FHIT gene alterations play a role in human solid tumors? Asia Pac J Clin Oncol. 2018; 14:e214-23.

\section{Publisher's Note}

Springer Nature remains neutral with regard to jurisdictional claims in published maps and institutional affiliations.

Ready to submit your research? Choose BMC and benefit from

- fast, convenient online submission

- thorough peer review by experienced researchers in your field

- rapid publication on acceptance

- support for research data, including large and complex data types

- gold Open Access which fosters wider collaboration and increased citations

- maximum visibility for your research: over 100M website views per year

At BMC, research is always in progress.

Learn more biomedcentral.com/submissions 